\title{
Desain Floating Modern Fishing Industry untuk Pengembangan Sektor Perikanan di Kepulauan Selayar, Sulawesi Selatan
}

\author{
Muhammad Fudail Andi Palinrungi dan Hesty Anita Kurniawati \\ Departemen Teknik Perkapalan, Fakultas Teknologi Kelautan, \\ Institut Teknologi Sepuluh Nopember (ITS) \\ e-mail: tita@na.its.ac.id
}

\begin{abstract}
Abstrak-Wilayah Kabupaten Kepulauan Selayar terdiri dari 130 buah gugus pulau besar dan kecil dengan luas keseluruhan wilayahnya mencapai $10.503,69 \mathrm{~km}^{2}$ yang terdiri dari daratan $\left(1.357,03 \mathrm{~km}^{2}\right.$ atau $\left.12,92 \%\right)$, dan lautan $\left(9.146,66 \mathrm{~km}^{2}\right.$ atau $\mathbf{8 7 , 0 8 \%}$. Dengan wilayah laut seluas $87 \%$ dari total wilayahnya, Kepulauan Selayar memiliki potensi yang cukup besar di sektor kelautan dan perikanan. Berdasarkan potensi tersebut gagasan Floating Modern Fishing Industry diharapkan dapat menarik peminat calon investor sambil mendukung industri perikanan lokal serta program Pemerintah Indonesia. Ukuran utama yang didapatkan berdasarkan luasan yang mengacu pada pabrik pengolahan ikan yang disesuaikan dengan rasio perbandingan ukuran utama dari kapal pembanding dan regulasi yang ada maka didapatkan $\mathrm{LoA}=105 \mathrm{~m}, \mathrm{~B}=22 \mathrm{~m}, \mathrm{H}=6 \mathrm{~m}, \mathrm{~T}=4.2 \mathrm{~m}$. dengan hasil olahan berupa ikan fillet dan tepung ikan serta terdapatnya budidaya perikanan. Analisis teknis yang dilakukan meliputi perhitungan berat, perhitungan stabilitas, perhitungan trim, dan perhitungan freeboard dan akan dilanjutkan dengan mendesain rencana garis, rencana umum, safety plan serta desain model tiga dimensinya dan dilakukan juga analisis ekonomis. Garbage disposal management menggunakan compactor yang diperuntukkan untuk jenis sampah plastik dan sampah nonorganic dan menggunakan comminuter untuk sampah yang berasal dari sisa-sisa makanan dan juga bahan-bahan organik. Sewage treatment management menggunakan holding tank serta konfigurasi mooring system yang digunakan adalah single point mooring system dengan biaya total pembangunan sebesar Rp 90.974.767.520.
\end{abstract}

Kata Kunci-Floating Modern Fishing Industry, Kepulauan Selayar, Sulawesi Selatan, Fillet, Tepung Ikan.

\section{PENDAHULUAN}

$\mathrm{S}$ EPERTIGA wilayah Indonesia merupakan perairan, maka tidak heran jika sumber daya kelautan dan perikanan sangat berlimpah ruah. Pemerintah pun terus berusaha untuk meningkatkan hasil industri perikanan untuk mencapai hasil maksimal dengan berbagai cara dan strategi.

Kabupaten Kepulauan Selayar memiliki panjang garis pantai sekitar $670 \mathrm{~km}$ dengan jumlah pulau kecil sebanyak 130 pulau, dan luas laut sekitar 9.146,66 km2, sehingga sangat potensial untuk kegiatan penangkapan ikan dan budidaya. Kepulauan Selayar mempunyai peluang yang prospektif untuk dikembangkan adalah pengadaan Sarana dan Prasarana, Kemitraan, dan Industri Pengolahan.

Sepanjang 2017, Kementerian Kelautan dan Perikanan (KKP) mengestimasikan total produksi perikanan tangkap mencapai 7,67 juta ton, atau setara Rp 158 triliun. Angka itu meningkat dibanding total produksi perikanan pada 2016 yang sebesar 6,54 juta ton atau senilai Rp 121 triliun. KKP memberi target signifikan untuk sektor perikanan budidaya pada 2018. Produksi ditargetkan bisa melambung ke angka 24,08 juta ton atau naik hampir 3 juta ton dari 2017 yang ditarget mencapai 22,46 juta ton.

Dilansir presidenri.go.id sektor perikanan berpotensi besar, tapi belum tergarap secara maksimal. Salah satu masalah utama bagi pengembangan industri perikanan di wilayah Sulawesi Selatan dan Kepulauan Selayar khususnya adalah infrastruktur. Berdasarkan potensi besar Indonesia dan program Pemerintah Indonesia untuk mengembangkan industri perikanan. Dengan demikian, gagasan Floating Modern Fishing Industry diharapkan dapat menarik peminat calon investor sambil mendukung industri perikanan lokal serta program Pemerintah Indonesia.

\section{TINJAUAN PUSTAKA}

\section{A. Tinjauan Wilayah}

Wilayah Kabupaten Kepulauan Selayar terdiri dari 130 buah gugus pulau besar dan kecil dengan luas keseluruhan wilayahnya mencapai $10.503,69 \mathrm{~km}^{2}$ yang terdiri dari daratan $\left(1.357,03 \mathrm{~km}^{2}\right.$ atau $\left.12,92 \%\right)$, dan lautan $\left(9.146,66 \mathrm{~km}^{2}\right.$ atau 87,08\%. Secara Administratif, Kabupaten Kepulauan Selayar terbagi dalam 11 kecamatan, 5 diantaranya berada di Kepulauan dan 6 kecamatan lainnya berada di daratan Pulau Selayar.

\section{B. Bangunan Apung}

Dewasa ini dan di masa depan, diperkirakan struktur bangunan terapung akan menjadi primadona konstruksi. Keuntungannya adalah tidak menimbulkan scouring pada pondasi pilar sebagai penumpu bangunan. Pilar konvensional umumnya mengalami masalah scouring atau gerusan yang dapat membahayakan pondasi struktur. [1]

\section{Fishing Industry}

Industri perikanan, bisa juga disebut dengan industri penangkapan ikan adalah industri atau aktivitas menangkap, membudidayakan, memproses, mengawetkan, menyimpan, mendistribusikan, dan memasarkan produk ikan. Istilah ini didefinisikan oleh Food and Agriculture (FAO), mencakup juga yang dilakukan oleh pemancing rekreasi, nelayan tradisional, dan penangkapan ikan komersial. [2] 


\section{Cold Storage}

Cold Storage adalah ruangan yang dirancang khusus untuk keperluan penyimpanan dengan suhu tertentu. Tujuannya adalah mepertahankan kesegaran produk yang disimpan untuk keperluan distribusi ataupun lainnya. Dalam dunia perikanan, Cold Storage digunakan untuk menyimpan hasil tangkapan ikan dan menahan laju pembusukan, sehingga hasil tangkapan ikan tetap memiliki harga jual yang tinggi.

\section{METODOLOGI PENELITIAN}

\section{A. Diagram Alir}

Tahapan dari metodologi penelitian yang digunakan digambarkan pada diagram alir pada Gambar 1.

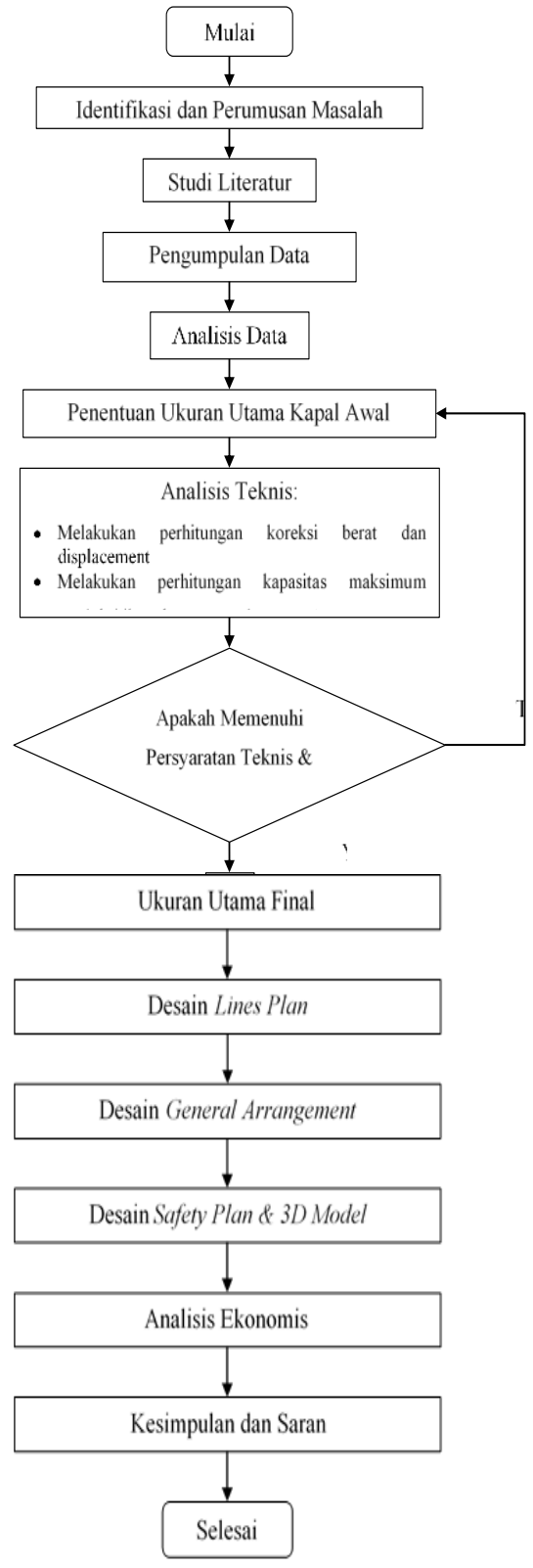

Gambar 1. Diagram Alir Metode.

\section{ANALISIS TEKNIS}

\section{A. Analisis Lokasi}

Didasarkan pada pertimbangan fungsi Floating Modern Fishing Industry ini, maka lokasi penempatannya sebaiknya bisa dijangkau oleh pulau-pulau yang ada di Kepulauan Selayar. Hal ini untuk memaksimalkan peran pengembangan sektor perikanan untuk Kepulauan Selayar. Adapun lokasi dari Floating Modern Fishing Industry ini berada di daerah Laut Flores yang termasuk dalam bagian WPP-RI 713. Lokasi dapat dilihat pada Gambar 2.

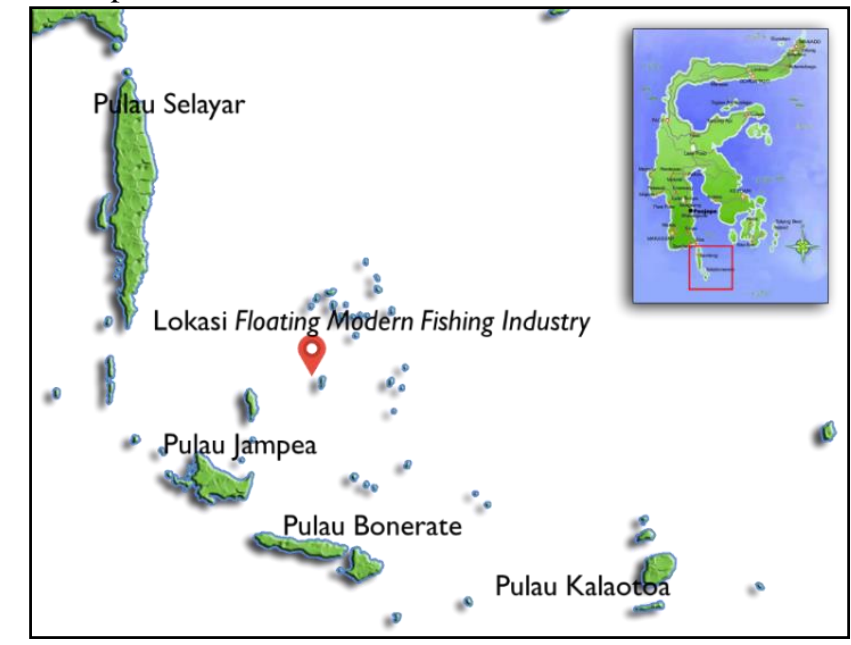

Gambar 2. Lokasi Floating Modern Fishing Industry.

Lokasi penempatan berada di Laut Flores yang memiliki kedalaman sekitar 20-200 meter. Lokasi penempatan Floating Modern Fishing Industry berdasarkan penulusuran google map berada pada koordinat $6^{\circ} 44^{\prime} 53.2^{\prime \prime S} 120^{\circ} 57^{\prime} 43.9^{\prime \prime} \mathrm{E}$. dan berjarak sekitar 200-300 meter dari pulau Jinatung, Kepulauan Selayar.

\section{B. Payload}

Payload pada kapal ini didapatkan dari total produksi ikan tangkap Kepulauan Selayar pada tahun 2018 dalam ton kemudian dikurangkan dengan konsumsi ikan penduduk Kepulauan Selayar dan ditambahkan dengan Produksi Budidaya yang akan dihasilkan pada kapal ini. Waktu produksi diasumsikan 15 hari dengan asumsi berat ikan berkurang 50\% setelah diolah.

\section{Payload $=$ Total Produksi Ikan - Konsumsi Ikan Penduduk + Produksi Budidaya}

Setelah itu dilakukan perhitungan payload didapatkan produksi per hari sebesar 46.01 ton. Sehingga total produksi dalam 15 hari menjadi 345.04 ton.

\section{Ukuran Utama Kapal}

Pada pengerjaan penelitian ini, penentuan ukuran utama Floating Fishing Modern Industry mengacu pada beberapa poin yakni sebagai berikut:

- Luasan pabrik pengolahan ikan

- Volume Ruang Muat

Mengacu pada dua poin di atas didapatkan ukuran utama awal Floating Modern Fishing Industry dapat dilihat pada Gambar 3. 


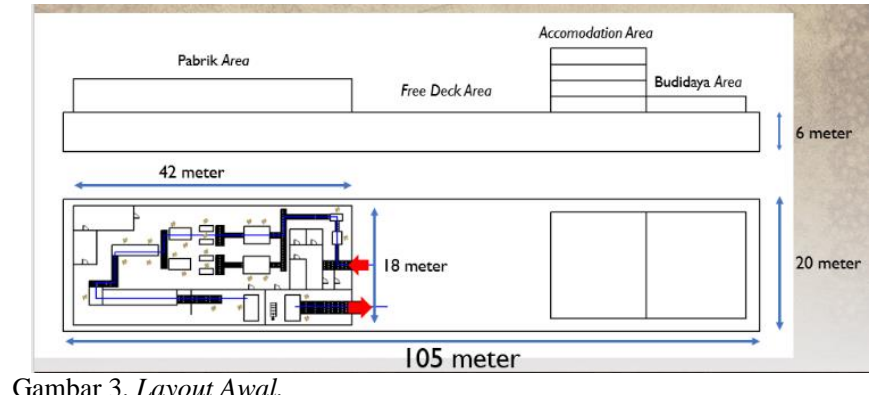

Gambar 3. Layout Awal.

Adapun dari ukuran utama awal tersebut dilakukan analisis teknis sesuai regulasi yang ada. Regulasi yang menjadi acuan yaitu International Convention of Load Lines (ICLL) tahun 1969 [3], Intact Stability (IS) Code Ch. III/3.5 [4], SOLAS Reg.II/7 yaitu nilai trim tidak boleh melebihi batasan yaitu $0.5 \%$ dari Lwl [5]. Setelah melakukan proses perhitungan dan pengecekan didapatkan.

Berdasarkan Tabel 1 diketahui bahwa nilai dari analisis teknis memenuhi kriteria dari regulasi. Sehingga ukuran utama akhir kapal menjadi:

$$
\begin{aligned}
& \text { - } \operatorname{LoA}=105 \mathrm{~m} \\
& \text { - } \mathrm{B}=22 \mathrm{~m} \\
& \text { - } \mathrm{H}=6 \mathrm{~m} \\
& \text { - } \mathrm{T}=3.7 \mathrm{~m}
\end{aligned}
$$

\section{Mooring System}

Konfigurasi mooring system menggunakan Single Point Mooring (SPM) system dengan tipe catenary anchor leg mooring (CALM). Pemilihan SPM berdasarkan kedalaman laut pada lokasi yang berkisar 20-200 meter, serta untuk mempermudah proses bongkar muat yang terletak pada bagian buritan kapal jika dibandingkan dengan tipe spread mooring system yang dapat mengganggu aktifitas bongkar muat tersebut

\section{E. Proses Pengolahan Ikan}

Secara umum proses pengolahan ikan, dapat disederhanakan menjadi beberapa kegiatan dasar:

1) Persiapan

2) Proses Kotor

3) Proses Bersih

4) Proses Beku

5) Pengemasan dan Penyimpanan

\section{F. Sistem Bongkar Muat}

Floating Modern Fishing Industry menggunakan side by side yang nantinya akan dibantu dengan crane dalam pemindahan muatan.

\section{G. Proses Budidaya}

Proses budidaya pada Floating Modern Fishing Industry menggunakan teknologi Keramba Jaring Apung (KJA) Offshore. Floating Modern Fishing Industry berfungsi sebagai ruang kontrol, advanced feed system feed silo, blower, rumah jaga, ruang mesin, gudang pakan dan air bersih. Jenis ikan yang dibudidayakan dalam instalasi budidaya ini KJA Offshore berupa ikan kerapu yang juga merupakan komoditas utama dari Kepulauan Selayar.

\section{H. Desain Rencana Garis (Lines Plan)}

Pembuatan Lines Plan merupakan tahapan dimana desainer dapat mendapatkan gambaran umum tentang bentuk kapal. Proses ini adalah salah satu proses dasar agar dapat mengerjakan rencana umum yang berisi tentang pembagian ruangan dan juga hal-hal jenis lainnya.

Pembuatan Lines Plan untuk Floating Modern Fishing Industry ini menggunakan software. Pengerjaan Lines Plan akan mendapatkan komponen-komponen berupa Body Plan, Sheer Plan, dan Half Breadth Plan. Gambar bisa dilihat pada Gambar 4.

\section{Desain Rencana Umum}

Rencana umum atau General Arrangement dari suatu kapal dapat didefinisikan sebagai penentuan dari ruangan kapal untuk segala kegiatan ( fungsi ) dan peralatan yang dibutuhkan sesuai dengan letak dan jalan untuk mencapai ruangan tersebut.

Pembuatan rencana umum/General Arrangement dilakukan dengan bantuan software. General Arrangement mengikuti desain Lines Plan dan menyesuaikan beberapa ketentuan, seperti geladak akomodasi yang cukup untuk para awak kapal, luasan yang dibutuhkan oleh muatan dan ketentuan lainnya. Gambar bisa dilihat pada Gambar 5.

\section{J. Desain 3D Model}

Ilustrasi 3D modelling pada software secara garis besar menggambarkan ruangan ruangan yang ada. Ilustrasi ini memudahkan dalam menvisualisasikan desain kapal sehingga menjadi acuan dalam evaluasi rencana umum serta ketersesuainnya dengan hal-hal yang seharusnya. Dapat dilihat pada Gambar 6.

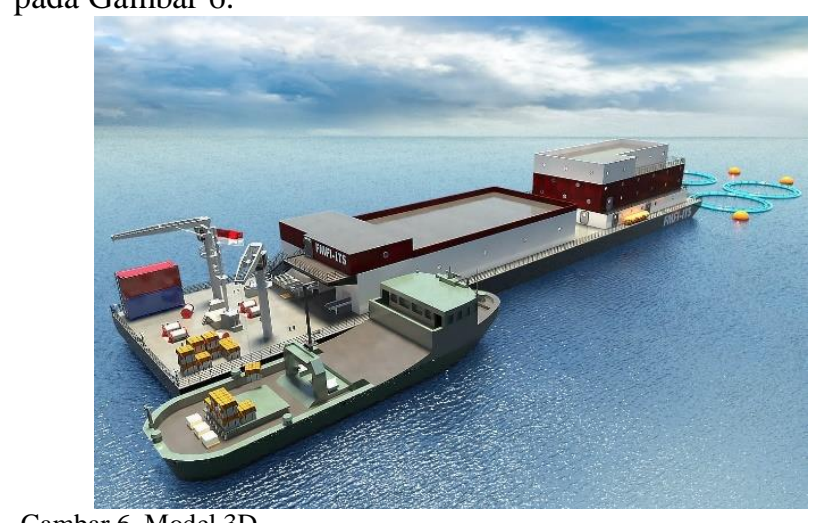

Gambar 6. Model 3D.

\section{K. Desain Safety Plan}

Perencanaan keselamatan kapal sangat diperlukan khususnya pada kapal yang mengangkut banyak penumpang. Oleh karena itu, harus disiapkan safety plan dengan memperhitungkan jumlah orang yang ada di kapal. Gambar dapat dilihat pada Gambar 7.

\section{Garbage dan Sewage Management Plan}

Untuk perencanaan garbage management plan adalah menggunakan compactor yang diperuntukkan untuk jenis sampah plastik dan sampah non-organic dan menggunakan 
comminuter dan macerator untuk sampah yang berasal dari sisa-sisa makanan dan juga bahan-bahan organik. Dikarenakan tidak diperbolehkan untuk membuang sampah ke laut dalam radius $12 \mathrm{~nm}$, maka disediakan holding tank untuk sementara sebelum sampah dibuang di port. Untuk perencanaan sewage menegement plant menggunakan comminuter untuk mengolah solid sewage dan penyediaan holding tank.

\section{ANALISIS EKONOMIS}

\section{A. Biaya Pembangunan}

Perhitungan (estimasi) biaya pembangunan kapal dilakukan dengan menghitung biaya main ship building cost. Setelah itu dilakukan perhitungan biaya electricity equipment, machinery part, contruction cost, miscellaneous, dan inderc cost dengan menggunakan presentase untuk masing-masing part yang mengacu pada pembangunan kapal baru dari PT. Pertamina dan kemudian ditambahkan dengan estimasi bunga bank. Didapatkan biaya pembangunan kapal sebesar $\mathrm{Rp}$ 90.974.767.520.

\section{B. Biaya Operasional}

Biaya operasional meliputi gaji crew dan karyawan, bahan bakar dan pelumas, serta pengeluaran tetap. Didapatkan biaya operasional kapal sebesar Rp 101.978.240.000

\section{Payback Period (PP)}

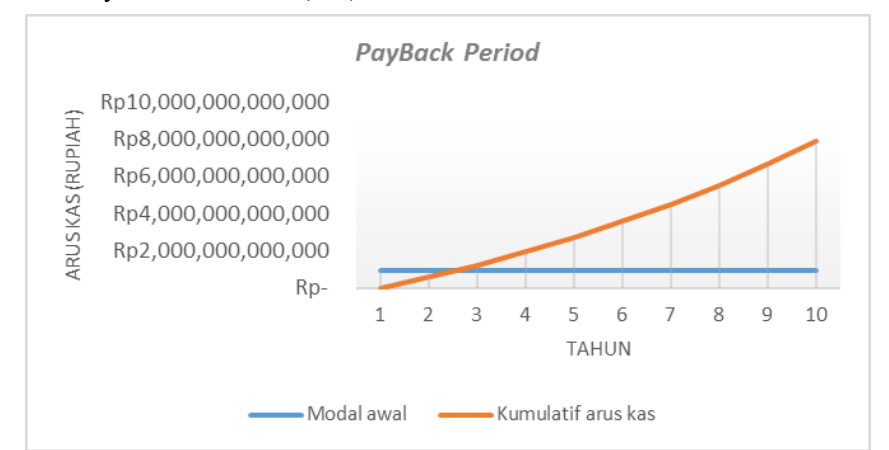

Gambar 8. Grafik Payback Period.

Didapatkan pay back period untuk Floating Modern Fishing Industry berada pada 2.9 tahun dapat dilihat pada Gambar 8 .

\section{Break Event Point (BEP)}

Perhitungan BEP pada Floating Modern Fishing Industry mengacu pada Fixed Cost, Variabel Cost dan Harga jual Didapatkan BEP pada produksi ke-125.

\section{E. Net Present Value (NPV) dan Internal Rate of Return (IRR)}

NPV dan IRR digunakan dalam penganggaran modal untuk menganilisis probabilitas investasi yang diproyeksikan dan bertujuan untuk mengukur seberapa besar nilai untuk stakeholder, proses capital budgeting dapat dilihat sebagai langkah untuk memulai investasi. Jika NPV bernilai positif investasi dapat diterima dan jika NPV bernilai negatif sebaiknya investasi ditolak Jika nilai IRR lebih besar dari bunga pinjaman maka investasi dapat diterima dan sebaliknya.

Berdasarkan Tabel 2 dapat dilihat nilai NPV > 0 dan nilai IRR > bunga pinjaman dimana nilai NPV sebesar Rp 2,893,741,084,448 dan nilai IRR sebesar $48.19 \%$ maka dapat dikatakan bahwa Floating Modern Fishing Industry layak untuk diinvestasikan.

\section{KESIMPULAN}

1. Lokasi yang dipilih berada pada WPP-RI 713 dan berada di bagian tengah dari Kepulauan Selayar.

2 Berdasarkan hasil produksi ikan di Kepulaun Selayar maka telah didapatkan nilai dari payload-nya yaitu 16791.91 ton.

3. Ukuran utama Floating Modern Fishing Industri yang didapat adalah:

$\begin{array}{ll}\text { - Length Overal } & : 105 \text { meter } \\ \text { - Breadth } & : 22 \text { meter } \\ \text { - Draught } & : 3.7 \text { meter } \\ \text { - Depth } & : 6 \text { meter } \\ \text { - Block Coefficient }: 0.918\end{array}$

4. Proses budidaya menggunkan teknologi Keramba Jaring Apung (KJA) Offshore dan proses bongkar muat menggunakan metode side by side off-loading.

5. Desain Rencana Garis, Desain Rencana Umum, dan Desain 3 dimensi serta gambar Safety Plan selengkapnya terlihat pada Gambar 3-4, Gambar 7.

6. Konfigurasi mooring system yang digunakan adalah Single Point Mooring (SPM) system dengan tipe catenary anchor leg mooring (CALM).

7. Untuk perencanaan garbage management adalah dengan menggunakan compactor untuk jenis sampah plastik dan sampah non-organic dan menggunakan comminuter dan macerator untuk sampah yang berasal dari sisa makanan dan juga bahan-bahan oraganik. dikarenakan tidak diperbolehkan membuang segala jenis sampah ke laut dalam radius $12 \mathrm{~nm}$. Sehingga pembuangan sampah akan dilakukan rutin setiap kapal pengantar consumable datang.

8. Untuk perencanaan sewage management adalah Floating Modern Fishing Industry harus dilengkapi dengan comminuter untuk penanggulangan solid sewage waste dan memiliki fasilitas penyimpanan sementara untuk sewage yakni Holding Tank.

9. Besarnya biaya total pembangunan sebesar Rp 90.974.767.520 dengan estimasi terjadinya Payback Period pada 2.9 tahun setelah beroperasi serta nilai NPV Rp 2.893.741.084.448 dan nilai IRR sebesar 48.19\%. 


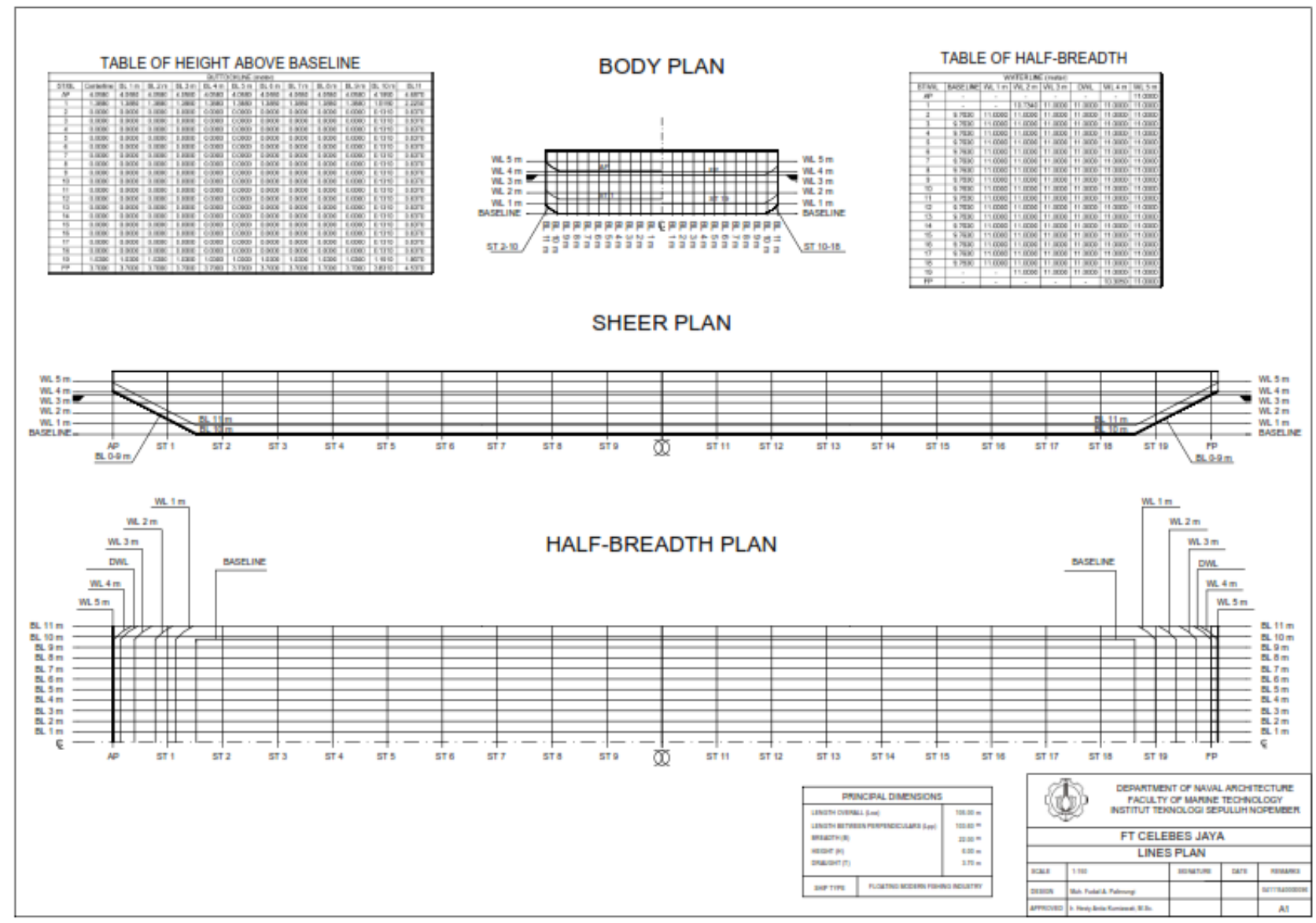

Gambar 4. Lines Plan.

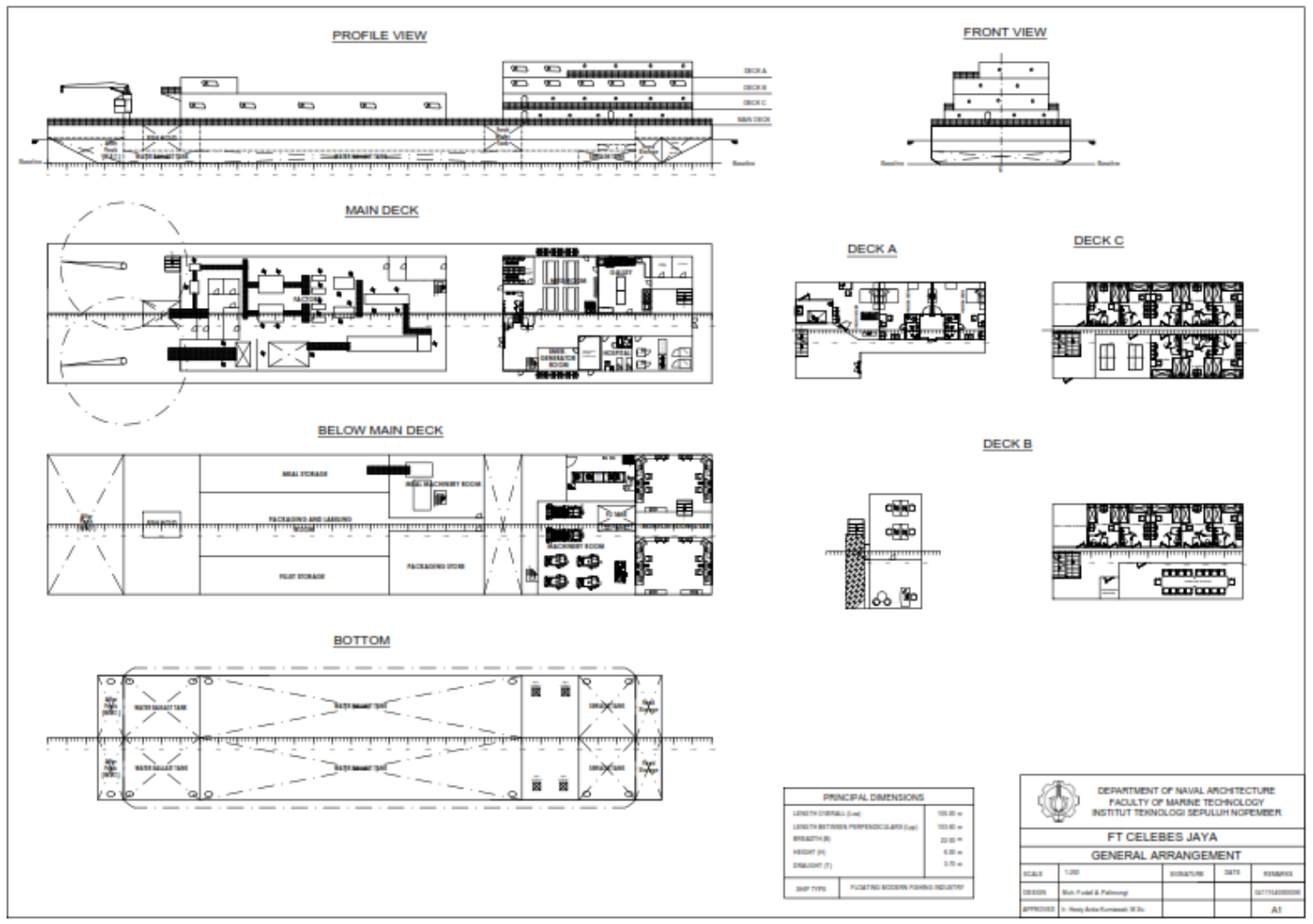

Gambar 5. General Arrangement. 


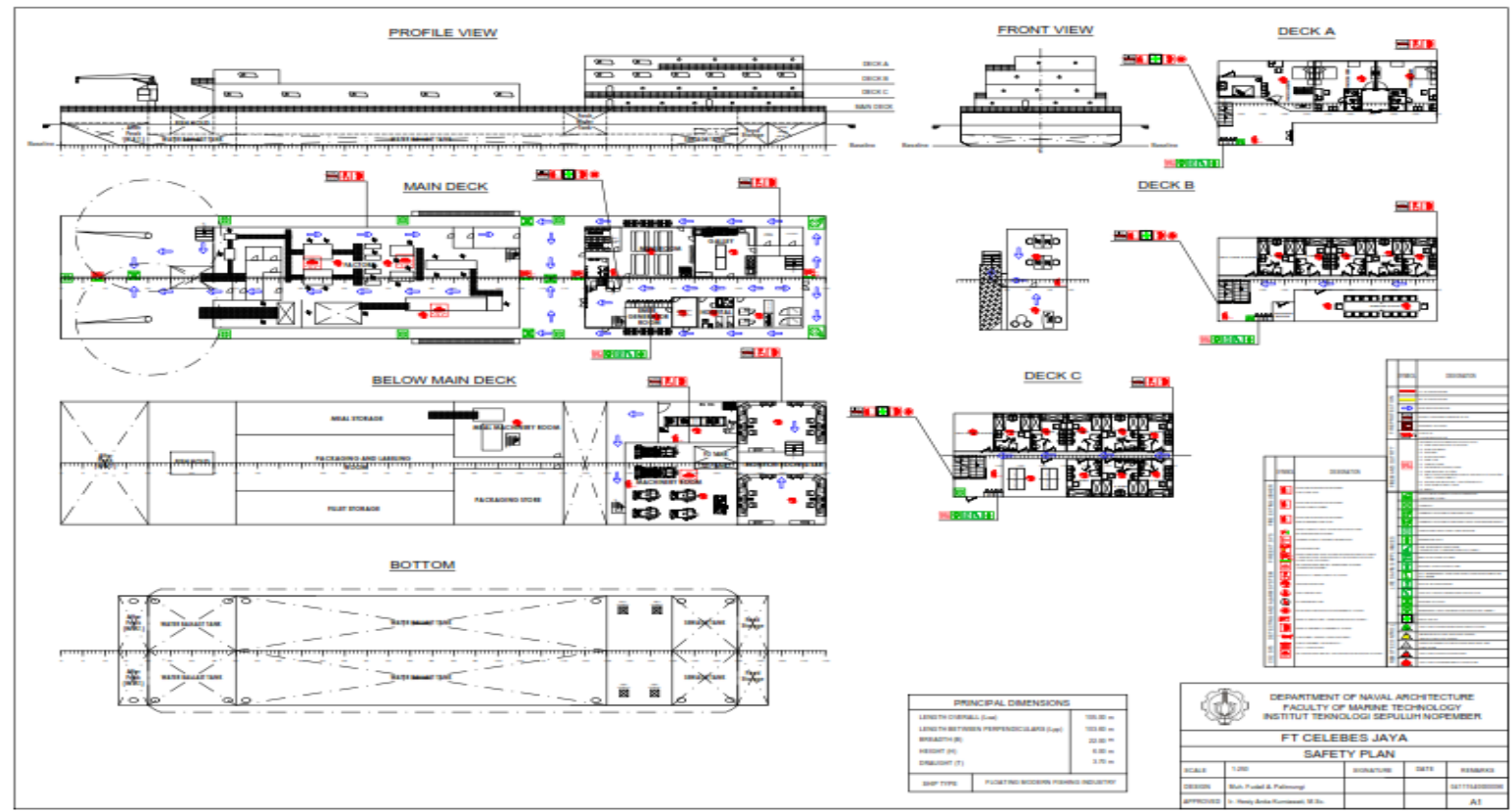

Gambar 7. Safety Plan.

Tabel 1.

Hasil Analisis Teknis

\begin{tabular}{|c|c|c|c|c|c|c|}
\hline Analisis Teknis & Item & Unit & Min & Value & Max & Remark \\
\hline & LWT & ton & - & 2015.106 & - & \\
\hline Koreksi & DWT & ton & - & 5278.12 & - & \\
\hline \multirow[t]{2}{*}{ Displacement } & Displacement & ton & - & 7935.146 & - & \\
\hline & Margin & & $2 \%$ & $8 \%$ & $10 \%$ & ok \\
\hline \multirow{2}{*}{ Freeboard } & Syarat & $\mathrm{m}$ & - & 1.24 & - & \\
\hline & Desain & $\mathrm{m}$ & 1.24 & 2.3 & - & ok \\
\hline \multirow{6}{*}{ Stabilitas } & $e_{0.30^{\circ}}$ & m.rad & 0.055 & 1.483 & - & ok \\
\hline & $e_{0.40^{\circ}}$ & m.rad & 0.09 & 2.183 & - & ok \\
\hline & $e_{30.40^{\circ}}$ & m.rad & 0.03 & 0.7 & - & ok \\
\hline & $h_{30^{\circ}}$ & $\mathrm{m}$ & 0.2 & 4.155 & - & ok \\
\hline & $\varphi_{G Z \max }$ & deg & 25 & 25 & - & ok \\
\hline & $G M_{0}$ & $\mathrm{~m}$ & 0.15 & 9.97 & - & ok \\
\hline \multirow{2}{*}{ Trim } & Syarat & & - & 0.518 & - & \\
\hline & Desain & & 0.518 & 0.234 & - & ok \\
\hline
\end{tabular}

Tabel 2.

Nilai NPV dan IRR

\begin{tabular}{|c|c|c|c|c|c|}
\hline \multirow[b]{2}{*}{ Tahun } & & \multirow[b]{2}{*}{ Arus Kas } & \multicolumn{3}{|c|}{ Tingkat Diskonto 13,5\% } \\
\hline & & & $\begin{array}{l}\text { Discount } \\
\text { Factor }\end{array}$ & & Present Value \\
\hline 2019 & $\mathrm{Rp}$ & $952,387,430,824$ & 1.000000000 & $\mathrm{Rp}$ & $952,387,430,824$ \\
\hline 2020 & $\mathrm{Rp}$ & $588,336,384,689$ & 0.874505348 & $\mathrm{Rp}$ & $514,503,314,807$ \\
\hline 2021 & $\mathrm{Rp}$ & $644,711,869,316$ & 0.756690765 & $\mathrm{Rp}$ & $487,847,517,597$ \\
\hline 2022 & $\mathrm{Rp}$ & $706,780,521,429$ & 0.658229968 & $\mathrm{Rp}$ & $465,224,120,003$ \\
\hline 2023 & $\mathrm{Rp}$ & $775,111,657,775$ & 0.572580914 & $\mathrm{Rp}$ & $443,814,141,461$ \\
\hline 2024 & $\mathrm{Rp}$ & $850,331,526,780$ & 0.498076538 & $\mathrm{Rp}$ & $423,530,183,011$ \\
\hline 2025 & $\mathrm{Rp}$ & $933,129,001,708$ & 0.433266690 & $\mathrm{Rp}$ & $404,293,713,913$ \\
\hline 2026 & $\mathrm{Rp}$ & $1,024,261,843,151$ & 0.376889917 & $\mathrm{Rp}$ & $386,033,961,052$ \\
\hline 2027 & $\mathrm{Rp}$ & $1,124,563,587,763$ & 0.327848903 & $\mathrm{Rp}$ & $368,686,938,602$ \\
\hline 2028 & $\mathrm{Rp}$ & $1,234,951,125,858$ & 0.285189120 & $\mathrm{Rp}$ & $352,194,624,826$ \\
\hline \multirow{2}{*}{\multicolumn{4}{|c|}{$\begin{array}{l}\text { NET PRESENT VALUE (10 Tahun) } \\
\text { INTEREST RATE RETURN }\end{array}$}} & $\mathbf{R p}$ & $2,893,741,084,448$ \\
\hline & & & & & $48.19 \%$ \\
\hline
\end{tabular}




\section{DAFTAR PUSTAKA}

[1] D. Mahardika, "Analisis teknis dan ekonomis pengembangan industri rumah apung sebagai pendukung wisata bahari indonesia," ITS Surabaya, 2017.

[2] The Food and Agriculture Organization (FAO), "Fisheries and aquaculture in our changing climate policy brief of the FAO for the UNFCCC COP-
15." Copenhagen, 2009.

[3] IMO, International Convention on Load Lines. London: Lloyd's Register, 1966.

[4] I. maritime O. (IMO), Intact Stability Code, Intact Stability for All Types of Ships Covered. London, 2008.

[5] I. M. Organization, International Convention for the Safety of Life at Sea. London: IMO, 1988. 